\title{
Performing Abjection in Wafaa Bilal's Domestic Tension
}

\author{
HANY ALI MAHMOUD ABDELFATTAH \\ Department Of English, Faculty Of Alsun, \\ Minia University, Egypt \\ h.a.abdelfattah@gmail.com
}

\begin{abstract}
This paper is a psychoanalytic literary study of the online performance Domestic Tension (2007) by the IraqiAmerican artist Wafaa Bilal. Fundamentally built on the psychoanalytic theories of Sigmund Freud and Jacques Lacan, Julia Kristeva's theory of abjection is well suited to be the critical tool to analyse the online performance Domestic Tension. This paper questions the performance as a manifestation of abjection that espouses Bilal's anti-Iraq War stance, by exposing the killing of thousands of Iraqis by the US drones. Furthermore, it investigates how the Brechtian theatrical techniques are used to restrain the cathartic experience of the viewers-cum-shooters, inviting them to 'disavow' Bilal's body, abstain from any cannibalistic desires, and finally to think of the consequences of the US invasion of Iraq.
\end{abstract}

Keywords: Domestic Tension; Wafaa Bilal; Julia Kristeva; Abjection; Cyborg

\section{INTRODUCTION}

This paper sets out to examine the notion of performing abjection in Wafaa Bilal's Domestic Tension by using Julia Kristeva's theory of abjection published in her book Powers of Horror: An Essay on Abjection (1982). Wafaa Bilal, an Iraqi artist, incarcerates himself for a month in an installation art gallery, where viewers can log on the internet to contact or shoot him with a robotic paintball gun. Bilal--in a black vest, goggles, and Palestinian Keffiyah--runs around the room to evade the shots of the viewers with no safety or food for a month. Drawing on Julia Kristeva's theory of abjection and the works of her predecessors Sigmund Freud and Jacques Lacan, this paper is a psychoanalytic literary study which attempts to demonstrate the presence or the absence of the manifestations of abjection in arts and literature. The paper explores the transformation of Bilal's body into an abject body, focusing on the terror he has witnessed and the conveyance of this terror, which every Iraqi lives in for fear of being killed by the US drones, to the online viewers and shooters. It also probes the intersection of the theatre of abjection and the cyborg Theatre through examining the paintball robotic gun which is controlled from afar like drones. Furthermore, the paper investigates the Brechtian theatrical techniques which provide no cathartic experience to the audience, but rather a way to think of the horrors of the US modern warfare in Iraq.

\section{THEORY OF ABJECTION}

The choice of Julia Kristeva's theory of abjection to analyse the play is timely and topical. It is the only theory that provides a lens to investigate the status of the abjection of Wafaa Bilal. I hypothesize that being incarcerated in a filthy and horrific condition, vulnerable to shots from online viewers/shooters, and experiencing 'food loathing' and 'disavowal' are the conditions that make Wafaa Bilal an abject.

The key concepts of Julia Kristeva's theory of abjection are defined. These concepts are: 'abject,' 'maternal body,' 'food loathing,' and 'disavowal.' The first term 'abject' breaks 
down the binary opposition of the subject versus object which was previously introduced by Jacques Lacan. In her book Powers of Horror: An Essay on Abjection, Kristeva states that the subject and object are not opposed locations but complete identities. The abject is neither subject nor object but rather it threatens "the logical certainty of the subject/object or self/notself binarism" (Wolfreys 2003, 3). Kristeva asserts that the abject forms a constitutive outside on which normative selfhood and society depend: it is "the horror that [civilizations] seize on in order to build themselves up and function" (Kristeva, Powers 1982, 210). It is a combination of the self and the other; it is ambiguous, and its ambiguity "disturbs identity, system, order" (Kristeva, Powers 1982, 4). Moreover, the abject defies "assimilation into the group's way of life, such as its language, social behavior, and norms" (Mi 2019, 254). Therefore, the abject is placed out of the order and in horrific conditions where it is confronted with filth, waste, or corpse, as Satkunananthan confirmed that "There are many categories of the abject, ranging from nausea related to food to filth/defilement" $(2015,21)$.

The second term is the 'maternal body' in which Kristeva likens the separation (abjection) between the infant and his breastfeeding mother with the biblical ritual of circumcision of the infant, as she contends that "circumcision would thus separate one from the maternal feminine impurity and defilement; it stands instead of sacrifice" (Kristeva, Powers 1982, 99). She goes on to explain the intricate relationship between the infant and his mother and the constitution of the human psyche as she claims that abjection has two sides: one maternal and the other social, as Kelly Oliver writes:

\footnotetext{
In terms of the maternal body, the infant is weaned off of breast milk. In terms of the social, the infant learns that it is not an animal and therefore must abstain from incestuous, cannibalistic, or murderous urges. Therefore, abjection is a vital part of psychic development and necessary for weaning a child from its dependence on its mother's body. Kristeva also argues that abjection is part of the process of becoming a human being. ("Kristeva and Food" 2014, 1317)
}

Therefore, the maternal phase and the social phase are integral to the development of the infant. As a fundamental phase in the psychosexual development of the infant, abjection forces the infant to abandon breastfeeding and consequently becomes capable of abstaining from incestuous, cannibalistic, and other bestial behavior toward the mother and the society. Kristeva adds that when milk develops a skin on its surface; it is abjected, despite the fact that milk is "a medium that is common to mother and child, a food that does not separate but binds" (Powers 1982, 105). This abjection of the maternal body is what paves the way for the food taboos and the biblical food prohibitions which Kristeva discusses lengthily in her book. According to Kristeva, 'food loathing,' the third term, is "the most elementary and the most archaic form of abjection," it is the boundary between humans and nonhumans. (Powers 1982, 2). Unlike animals, the human body becomes "inedible, not literal flesh and blood that like animals can be consumed, but rather metaphorical flesh and blood" (Oliver "Kristeva and Food" 2014, 1319). That explains the sublimity of the body which "is imagined as the site where one discovers oneself 'whole,' and where one imagines oneself discovered whole by others" (Gillespie 2021, 166).

Abjection is a "disavowal," the fourth term of the study, that paves the way for the construction of its identity. Thus, the infant learns to mark the boundaries between what is legal and what is not in its community. In addition, the abject is marked by being uncategorized, as it is "neither fish nor fowl; but rather, it is the in-between that resists categorization." This resistance to categorization is what makes the abject provoke "fear and fascination" at the same time (Oliver "Kristeva and Food" 2014, 1317). 


\section{DOMESTIC TENSION: AN HISTORICAL PERSPECTIVE}

Many studies tackled Domestic Tension from the perspectives of technology, audience participation, geopolitics, and religion. From the perspective of technology, Domestic Tension was studied with a focus on social media as a stage. In the article "Social Media as Theatre Stage: Aesthetics, Affordances, and Interactivities," Bree Hadley reviewed many plays, such as National Theatre of Wales' The Radicalization of Bradley Manning, Adam Cass's I Love You Bro, Liesel Zink's Various Selves, Brian Lobel's Purge, and Wafaa Bilal's Domestic Tension. Hadley asserted that Domestic Tension was a big success, but it came with a very high price: Bilal suffered from post-traumatic stress disorder (PTSD) from the 65,000 shots he had received during the month of his installation project. He concluded that Domestic Tension was "an effort to make them (the audience) think about their attitude towards others" $(2017,90)$. In the article "Superhumans and Cyborgs," Sibel Deren Guler commented on Bilal's use of technology as an attempt to "connect to his audience and invite them to participate in his performances" $(2016,147)$.

Laura Levin's article "Embedded Performance" followed the contemporary performances of camouflage such as performative photography of Janieta Eyre; environmental, immersive, and site-specific performance of Liu Bolin; activist infiltration by The Yes Men, and solo artworks like Wafaa Bilal. She saw Domestic Tension as an eye-opener for "larger questions about dehumanizing modern technologies like drones, operated remotely by military personnel sitting at computers in a distant country" $(2014,137)$. In the dissertation "Art and Conversation: Disturbation in Public Space," Arthur C. Danto referred to political artworks that confronted spectators with "materials of reality in order to produce reactions that are continuous with those of real life" (Oketch 2018, 18). According to Danto, the distance between art and reality should dissolve and this could be done through "disturbation." By applying this theory to many political artworks, including Wafaa Bilal's Domestic Tension, the study concluded that the use of virtual reality in the performance encouraged "anti-social or dehumanizing behavior" as the audience was able to shoot from a distance.

Rachel Ruth Zylka's thesis Power Performance: Benevolence and Violence in the Work of Chris Burden, Barbara T. Smith, Yoko Ono and Wafaa Bilal traced the constant flux of power between the viewers and the performers in the way of who relinquished power to whom. Performers sometimes relinquish power to the viewers and turn to be 'powerless,' sometimes performers retain this power and impose on the viewers' certain restrictions. Drawing on the works of Chris Burden, Barbara T. Smith, Yoko Ono, and Wafaa Bilal, the audience reception and the power relations could be gauged and analysed. Alan Ingram's study "Experimental Geopolitics: Wafaa Bilal's Domestic Tension" examined Wafaa Bilal's Domestic Tension as a form of geopolitics in which the artist lived for a month in front of a webcam and paintball gun that could be controlled remotely via the internet. Ingram argued that "experimental tactics adopted by contemporary artists open up geopolitics for reflexive interrogation and creative refashioning in ways that were suggestive for alternative geopolitical projects" $(2012,123)$. Rachel Wagner's study "First-Person Shooter Religion: Algorithmic Culture and InterReligious Encounter" explored how religions and video games were providing the spectators with structures that gave them a temporary escape from their lives. The study also endeavored to prove that video games could do some of the functioning of religious activities. Now, it is evident that none of the aforementioned studies has tackled Domestic Tension as a performance of abjection, and the idea that the robotic gun is a cyborg has not been discussed or investigated either.

In the following part, I will trace the representation of abjection in art and literature. In arts, abjection flourished in the paintings of Mapplethorpe, Kiki Smith, and in the films of Andy Warhol where they depicted fleshly scenes of disease, waste, nudity, dismemberment, 
and fragmentation. For example, in Andy Warhol's film Beauty \#2, a half-undressed couple was filmed, lying in a bed, smoking and kissing. When the female revolted against the heterosexual life that the film stages and that operates then, this female is threatened with "exclusion altogether, as one who is worshipped and silenced, rendered abject and unpresentable, or_sometimes both" (Gilbertson 2003, 31-2).

In Literature, scenes of abjection were abundant in the novels of "Mary Shelley's Frankenstein and the Robert Mapplethorpe Self-Portrait" (Kutzbach 2007, 45). The most representable example of abjection is Franz Kafka's short story "The Hunger Artist." In his article "Performing Hunger: Fasting in Franz Kafka's Hunger Artist as Poetic Practice," Sabine Wilke asserted that Kafka's story reflected the cultural practice of fasting as "an artistic performance on the thematic level" and "a narratological problem" on the poetic level. It tells of an artist who makes a spectacle of himself through fasting. He tours numerous European cities, placing himself in a cage, and fasting for forty days. He is pleased when he sees crowds of people coming to visit. Some spectators are in doubt; they come late at night to check whether the hunger artist is hoarding any food to eat later. Gradually, the interest of people faded to watch the hunger artist in his emaciated look. They come to watch other tricks which beguiled them more. The hunger artist becomes worried and desperate; he turns skinny and aloof with his place dirty and disgusting. He is left as an abject to many spectators. Finally, he confesses to one of the watchers that had he found the food which tasted good to him, he would not have to fast at all.

In theatre, it was Antonin Artaud's Theatre of Cruelty which brought abjection to the theatre. Artaud deliberately introduced scenes of blood, pain, sex, and gore to shock the audience into experiencing the subconscious. His plays The Cenci and Jet of Blood revolutionized the stage by showing the audience scenes of abjection and death. The corpses had functions in his plays, as Kristeva confirmed, "An 'l' invaded by the corpse: such is often the abject in the text of Artaud ("Approaching Abjection" 1982, 144).

Afterward, the use of animal corpses was extensively used in the works of Hermann Nitsch in his Radical Theatre Group Orgien-Mysterien-Theatre which staged rituals using animal corpses and bloodshed to shock the audience, as the art critic Stefan Beyst confirmed:

No wonder that Nitsch comes to poach on the territory of Artaud and Sade. Things come to their apogee in the 'fantastic drama' 'Die Eroberung von Jeruzalem,' conceived for real corpses which Nitsch sarcastically calls 'the favorite of his opponents.

Artaud's performances were the spark that ignited the interest of many directors to perform abjection on the stage. Kira O'Reilly staged performances which involved animals, as she did in her play entitled Falling Asleep with a Pig (2009) in which O'Reilly lived with a live pig called Deliah for some days in a specially constructed sty, as she commented, "Falling Asleep with a Pig creates a situation where a human-animal (myself) and a non-human animal (a pig, specifically Deliah, a Vietnamese Potbellied pig) share a specially designed and constructed dwelling for 36 hours)" (Snæbjörnsdóttir 2017, 39). O'Reilly also staged a play entitled In the Wrong Places with "a female pig cadaver weighing approximately $48 \mathrm{kgs}$ that has been slaughtered for food consumption, so the internal organs have been removed" (Snæbjörnsdóttir 2017, 39).

Based on the debate of Domestic Tension from a historical perspective, it is found that there is a lack of scholarship on the study of Wafaa Bilal's Domestic Tension from a psychological perspective. This paper takes Wafaa Bilal's Domestic Tension as a case in point to show how other studies have marginalised the psychological perspective of this online performance and just focused on technology, audience participation, and geopolitics. Therefore, the paper makes a case for Julia Kristeva's theory of abjection as a methodology for 
analysing Domestic Tension, providing a new venue to watch the performance from a psychological perspective.

\section{DOMESTIC TENSION}

This portion examines Wafaa Bilal's online performance Domestic Tension (2007) as a performance of abjection based on Julia Kristeva's theory of abjection. There is a short introduction about Wafaa Bilal and the conditions of making the performance, people who helped him, obstacles that he faced, plot, themes, and techniques used throughout the online performance. The study relies primarily on the diary of Wafaa Bilal of the 30 days of the performance--published in his book Shoot an Iraqi: Art, Life, and Resistance Under the Gun, which also contains an autobiography of his formative years in Iraq--and on the online performance The Paintball Project on YouTube available at the URL https://youtu.be/EQ6XbZZIyVk.

The plot of the performance is composed of 30 episodes: each corresponds to a day of the 30 days of the online performance. It starts with 'Day 1' where Bilal feels discomfort from the stress and the constant shooting of the robotic gun until 'Day 30' where Bilal is extremely exhausted. His performance is always interspersed with Bilal's memories of Iraq, the tragic death of his brother, the tough days of Saddam Hussein, the horrors of the robotic gun, and his chats with the online viewers. By the end of the performance, Bilal's body completely deteriorates from the stress, the velocity of the bullets, and the insults hurled at him all day long. He has gained much weight and his body is full of wounds and cuts from the shots of the robotic gun.

Bilal collaborated with the Washington Post Journalist Kari Lydersen in turning his installation art gallery into a book entitled Shoot an Iraqi: Art, Life, and Resistance Under the Gun. In this book, Bilal gave important insights into his trajectory as an ordinary Iraqi, a refugee, and an artist, which could not be separated from the political and social context of the performance. In his book, Bilal incorporated a diary of his performance and an autobiography during his formative years in Iraq. The autobiography traced his childhood memories as well as his life as a refugee in Saudi Arabia until he was deported to the US in 2003. In his autobiography, Bilal stated that he was born in 1966 as a Shiite Muslim in Najaf, Iraq and that his formative years were marked by the horrific rule of Saddam Hussein. He also recounted memories of his turbulent relationship with a callous father. In 1991, he refused to participate in the invasion of Kuwait and fled to a refugee camp in Saudi Arabia, where he lived for two years before moving to the US in 1993. In America, he showed a remarkable talent in his art shows and galleries and began to spread awareness of the tragedy of the Iraqis after the American invasion in 2003. In 2005, Bilal launched the video game "The Night of Bush Capturing: A Virtual Jihadi" which was a hack of Al-Qaeda's video game "The Night of Bush Capturing" in which Al-Qaeda added "a new skin" to turn the old game "Quest of Saddam" into a hunt for Bush, as he confirmed that he "has hacked Al-Qaeda's version of the game to put his own more nuanced spin on this epic conflict" (Bilal, "A Virtual Jihadi"). Thereinafter, Bilal drew attention to his projects and art galleries. In 2015, Bilal created an online performance entitled 168:01 to encourage donors worldwide to give to build the library of Baghdad.

In the book Shoot an Iraqi: Art, Life, and Resistance Under the Gun, the conditions underlying the initiating of Domestic Tension were revealed. In 2007, the performance was installed in Flat File galleries in Chicago, USA with the help of "Susan Aurinko, the owner of the FlatFile Galleries which were founded in Chicago, USA, in 2000. They include contemporary art and sculpture. Shawn Lawson was the artistic collaborator of the project, Ben 
Chang was the art institute professor, and Dan Miller was the art and technology professor who designed and assembled the robotic gun.

The idea of the play came to Bilal after the assassination of his brother Haji by a US drone in Iraq. Bilal was appalled by the disparity between the perpetrator and the victim, as he confirmed:

\begin{abstract}
In early 2007 I saw a TV interview with a young female American soldier whose job was to drop bombs remotely on Iraqi targets, directing them from a computer console in Colorado. It struck me that Haji's death had been orchestrated by someone just like this young woman, pressing buttons from thousands of miles away, sitting in a comfortable chair in front of a computer, completely oblivious to the terror and destruction they were causing to a family--a whole society--halfway across the world. (Bilal, Shoot 2013, 10)
\end{abstract}

The whole experience of killing his brother by a US drone in Iraq left Bilal traumatized. Therefore, he set up the project to show the world how detached were the US soldiers in modern warfare, as he said, "I need to connect to my life as an artist in the comfort zone of the United States to the terrors and sorrows of the conflict zone" (Bilal, Shoot 2013, 1).

Killing by drones placed the American viewers in front of the reality of modern warfare for the first time. Since time immemorial, a direct encounter between armies was the norm. After the killing of thousands of Americans in guerrilla warfare in Vietnam, the US developed non-conventional weapons to control the airspace of the enemy rather than sending troops to engage in direct battlefields. After September $11^{\text {th }}$ and the ensuing War on Terror, these weapons were widely developed to fight in Afghanistan and Iraq without military deployment. Drones were used at first in surveillance and then in combat zones. Run from thousands of miles away and by soldiers who were completely detached from the horrible reality of war, drones turned into advanced weapons that succeeded in keeping their enemies in constant fear.

\title{
A CRITICAL ANALYSIS OF ABJECTIOIN IN WAFAA BILAL'S DOMESTIC TENSION
}

Bilal performed abjection in two ways: first, he functioned as an abject by living in an undesirable state of being in his art gallery. Second, Bilal was accused of being a homosexual and that qualified him to be an abject. First, the living conditions in the art gallery were unbearable, as Becker asserted:

Each time I entered the space, I was brought to tears. What had once been a spotless, white-cube gallery had become, over a short time, startlingly chaotic...It seemed impossible to breathe, let alone sleep, eat, write, or think in such a space. As Wafaa wrote at the time, "The scene is like some natural disaster--except it's not natural. It's an entirely manmade disaster. That's what war is. $(2013, \mathrm{xv})$

The performance had taken a heavy toll on Bilal's body due to the sordidness, squalor, and inhumane conditions. The view from the webcam was ominous and eerie: Bilal gained much weight; he grew a beard; dark circles formed under his eyes; his voice became harsh; his clothes were disorderly; the room looked dirty and littered with glasses and plastics; and the robotic gun was unstoppable, following and shooting Bilal wherever he went. The only sounds heard were Bilal's movement, his panicky voice, his loud breathing, and the mechanic shots of the gun which are "like a sound of a ".45 caliber semiautomatic" (Becker 2013, xvi). The pellets are "shot with such velocity that one point they "cracked the protective Plexiglas shield behind which Wafaa can retreat to compose his thoughts and monitor the project's chat room on his computer" (Becker 2013, xv).

This robotic gun "was shot 65,000 times from online users in 136 countries" (Stevens 2014, 79), splattering Bilal and his surroundings, causing a "sticky, slippery, soupy yellow paint, whose fish-oil smell permeated everything" (Becker 2013, xv). The yellow-soaked image of Bilal provokes disgust and recalls Kristeva's theory of abjection which postulates that the bodily fluids such as menstrual period blood and breast milk cause abjection, as she holds: 
These body fluids, this defilement, this shit are what life withstands, hardly and with difficulty, on the part of death. There, I am at the border of my condition, as a living being. My body extricates itself, as being alive, from that border. Such wastes drop so that I might live, until, from loss to loss, nothing remains in me and my entire body falls beyond the limit--cadere, cadaver. (Powers 1982, 3)

The yellowish stain and the harsh conditions of the gallery provoke a sense of abjection in the viewers. In her article "The Abject Lover of the Courtly Love Era," Halimah Mohamed Ali describes abjection as a "threat, which surrounds us, but we do not know how to deal with it" $(2013,7)$. Some politicians exploit this sense of abjection to their favour. In a study titled "Disgust sensitivity, political conservatism, and voting," a large sample of Americans was questioned about their political views. The study concludes that "Disgust sensitivity was positively associated with political conservatism" (Inbar 2012, 541). Moreover, it seems especially likely to "affect judgments of acts that are related to sexual, bodily, or spiritual purity" (Inbar 2012, 537). In this respect, inducing disgust by politicians seems to temporarily shift people's moral judgments toward conservativism. Therefore, people start to vote based on their feelings of abjection toward acts that violate norms of sexual and bodily purity. As a case in point, former US President Donald Trump takes advantage of the people's feelings of abjection for his political causes and to justify his misogyny. When he wanted to "slam Foxnews anchor Megan Kelly for questioning him about his misogynistic comments in the first GOP primary debate," he said, "there is a blood coming out of wherever" (Gajanan 2016, 34). In this way, Trump attempted to use a bodily function to create disgust and revulsion instead of meeting her at an intellectual level.

Another thing that qualifies Bilal to be an abject is being accused of homosexuality. Bilal is labeled a homosexual by some online homophobic viewers although he is not explicitly labeled as such by the media outlets. These viewers write insulting remarks on his wall online.

I wanna have sex with him

Those are cum shots on the glass....

Baba ghanoush

Waterboard him...make him talk.

I'm gonna waffle his ... (Bilal, Shoot 2013, 83)

They aim the robotic gun, a phallus symbol, at Bilal's body and hurl insults and swearing words at him. In this context, the phallus--which is usually understood as "the signifier of being, the signifier of male authority and privilege" (Joodaki 2015, 168)--becomes a source of male anxiety in Bilal. For a month, Bilal runs from the shots of the robotic gun, powerless and exhausted, and his body is symbolically penetrated rather than penetrating.

Bilal is aware of shooters' lewd behavior and describes the performance as a "sexual metaphor" and adds that the shooters have "this testosterone-driven male impulse to fire, to ejaculate, to aggressively leave their slimy and pungent mark on a space or being before disappearing without a word" (Bilal, Shoot 2013, 134). In wars, it is evident that the two fighting parties seek to feminize each other by accusing each other of homosexuality and these wild accusations pave the way to demonize and degrade the other. The homosexual is an abject as Covino argues, in his study The Abject Body: Toward an Aesthetic of The Repulsive, that the abject is "the ugly, rather than the beautiful"; it is the "unwanted body, the homosexual" $(1996,8)$. As an abject, Bilal remains 'uncategorized' to the viewers as he is a hero to some and a mere homosexual to others. This can be explained only through abjection in which the abject "provokes both fear and fascination" (Oliver "Kristeva and Food" 2014, 1317).

Sometimes, sex and death are associated as when Bilal recounts a similar incident, back when he was in Najaf, Iraq, where hundreds of bodies were about to be buried and the Islamic traditions necessitated that they had to be washed--kids would sneak and climb on the roof of the washhouse and "peer into the courtyard just to see the naked women; some would lie there 
on the roof with their hands in their pants, masturbating" (Bilal, Shoot 2013, 70). This is exactly like the viewers/shooters of the performance who find that Bilal is an erotic object while living in filth and squalor. Some disavow his body, others indulge in 'eating' or eroticizing his body, as Bilal comments, "I often felt that way during the paintball project, when I was exhausted, stressed out and in pain, and the shooters were getting such a thrill from targeting me--I wouldn't be surprised if some of them were masturbating, too (Bilal, Shoot 2013, 39-40). These horrible living conditions and the accusation of being homosexual are all indications that Wafaa Bilal is performing abjection. Through abjection, Bilal distorts the order and ruptures the political stability of many Americans and worldwide viewers, shocking them into awakening, and placing them in the line of fire.

\section{TECHNIQUE}

Domestic Tension is abundant with techniques that aim to accentuate the status of the abjection of Wafaa Bilal and to disengage the audience from being under an illusion. The colour of the pellets of the robotic gun is one of these techniques. Blood denotes injury and the menstrual period, thus provoking feelings of disgust and abjection. However, Bilal uses yellow-coloured pellets in the robotic gun to remind the shooters that he is playing a game not presenting a slice of real life. Consequently, Bilal uses Brecht's alienation effects to disengage the viewers/shooters from fully indulging in this game and allows them to think about the reality of war without having any illusions.

Instead of causing catharsis, Domestic Tension drives the viewers to act positively. They start to notice the deterioration in Bilal's health and sympathize with him; therefore, they attempt to reverse the hacking of the robotic gun by writing scripts to turn the gun left and to keep it from shooting Bilal, as Becker confirms, "hackers had found a way to turn the gun into a machine gun, and the pellets were flying nonstop and out of control. Friends were reprogramming the gun, and others were taking up a collection to buy more paintballs" (2013, xvii). Saving Bilal becomes a mission to some viewers who are no longer captive audience but rather "co-creators" who log on to "reflect on the consequences of their remote, game-like, war-like relationship with an Other when encountering them online versus offline" (Hadley $2017,90)$. Thus, the number of viewers who begin to chat with Bilal, rather than shoot him, increases by the end of the performance. Some donate food, others participate in hacking the robotic gun to stop it and to save Bilal.

Like the unmanned drone, which killed Bilal's brother in Iraq, the robotic gun is a "cybernetic organism, a hybrid of machine and organism, a creature of social reality as well as a creature of fiction" (Haraway 1991, 150). Technically, it is controlled by the shooters, so it is part human and part machine. The human part appears when Bilal develops a connection to it and feels lonely when it stops, he says:

\footnotetext{
I felt as though I were watching my relationship with the gun. I despised it, cursed it, I never wanted to see or hear it again. But in that situation of isolation and stress, it was my steady companion, constantly alive and in motion. When it was silent, I felt lonely and abandoned. (Bilal, Shoot 2013, 93)
}

The machine part is exposed when the robotic gun pokes its head and roves around the room looking for Bilal everywhere until it finds him and shoots him mercilessly.

Whether Bilal is seen as lethargic, apathetic, and helpless, the robotic gun is regarded as Bilal's antithesis. It is vital, not apathetic; it works without stopping, and it is robust and decisive. The robotic gun is an ambiguous hybrid: it shifts identities since the viewers see it as a malemachine or a phallus by which they can shoot at Bilal. This phallus "defines everything" and "gives meaning to all objects" (Joodaki 2015, 168). It also causes male anxiety to Bilal with its uncanniness which bears a resemblance to the phallus. 
It is the agency of the shooters which constitutes a great disturbance and anxiety to Bilal, but Bilal strangely develops a connection to it. The robotic gun has turned, from an ordinary machine controlled from a distance, into a real rogue monster which acts on its own, triggering into memory the notorious case of an unmanned Reaper drone which acted out on its own and was about to shoot objects in Pakistan. In his article "Machine Rebellion Begins: Killer Robots Destroyed by the US Jet," Page Lewis asserted that "it was reported that the Reaper drone was shot down by a 'manned' US fighter Jet before it could carry out its (unilateral) invasion plans."

In his book Shoot an Iraqi, Bilal mentions clearly that he is not a martyr and he does not intend to be, as when he confirms, "I hate the idea of martyrdom in general; I believe in surviving" $(2013,75)$. However, the theatrical technique of Domestic Tension, where Bilal offers his body to be shot by the online viewers and before the whole world, bears a significant affinity to the Christian ceremony of the Eucharist, which, in turn, represents sacrifice. According to the Bible, the Eucharist or the Holy Communion is based on the incident where food and body exist before the communicants. Christ gives his disciples bread and wine and commands them to "do this in memory of me" (King James Bible Luke 22:19). The Sacrament, bread, and wine are to be consumed on the dining table. Roman Catholics believe that the Sacrament is the body and blood of the Christ himself. In this way, Christ offers his body to his disciples as a sacrifice for their sins, as he says, "Take, eat; this is my body" (King James Bible Matt 26:26). He also holds a cup of wine and says, "And he took a cup, and when he had given thanks he gave it to them, saying, 'Drink of it, all of you; for this is my blood" (King James Bible Matt 26:27). Overall, the majority of the Christian denominations celebrate the Eucharist which simply refers to Christ's sacrifice of himself on the cross.

In her book, Animal Lessons: How They Teach us to be Human, Kelly Oliver draws a comparison between the Eucharist in the book of Sigmund Freud's Totem and Taboo (1955) and Julia Kristeva's Powers of Horror. For Freud, the Eucharist is a "ritualistic repetition of the Totemic celebration of eating the father" $(2009,294)$. He traces the origin of the human sacrifice and how it changes to be an animal sacrifice, passing from the father to the son and finally to the animal. He starts by explaining how the law of talion (an eye for an eye) makes the humans demand a sacrifice in case of a murder, as he states, "The law of talion, which is so deeply rooted in human feelings, lays it down that a murder can only be expiated by the sacrifice of another life...And if this sacrifice of a life brought about atonement with God the Father, the crime to be expiated can only have been the murder of the father" (Totem and Taboo 1921, 179).

According to Christianity, the son replaces the father to achieve the full atonement from the sin, as Freud asserts, "He (the son) himself became God, beside, or, more correctly, in place of, the father." (1955, 179). Thus, for Freud, the Eucharist is "elimination of the father, a repetition of the guilty deed" $(1955,179)$. Meanwhile, Kristeva sees the Eucharist as "a disavowal of the mother, the primal 'object' of the urge to 'devour'" (Oliver 2009, 294). For Kristeva, bringing together body and bread is a taming of the cannibalistic desires, as she notes, "By surreptitiously mingling the theme of 'devouring' with that of 'satiating, 'that narrative (The Eucharist) is a way of taming cannibalism. It invites the removal of guilt from the archaic relation to the first pre-object (ab-ject) of need: the mother" (Powers 1982, 118).

Kristeva sees the move from the ritual of sacrifice to the ritual of purification as "a move away from violence and toward more sublimatory and therefore more humane forms of regulations. Her analysis sees ritual sacrifice as glorifying the violence of killing, whereas the rituals of purification sublimate it" (Oliver 2014, 295). Thus, Domestic Tension bears a great resemblance to the ritual of the Eucharist: Bilal's gallery is similar to the altar; and the webcam-which transmits the scene to the whole world online--is likened to the dining table of the Eucharist; the robotic gun has been used by the online shooters as an agency to 'devour' the 
flesh of Wafaa Bilal. In so doing, the online shooters, who come to celebrate, are the communicants who "consume" or 'devour' rather than sympathize with Bilal. These viewers were two different types: the first type just watched the performance, the second engaged by shooting. Thus, in Domestic Tension, the audience participation is a trap, since Wafaa Bilal succeeds to place the viewers in the shoes of the soldiers who control the drones from afar. Therefore, Domestic Tension is a ritual of the purification of the viewers-cum-shooters, as it seeks to domesticate the cannibalistic desires of the shooters through exposing Bilal's body, which functions as the maternal body--the body of Christ or the son who sacrifices his body instead of the body of the father--and consequently draws abjection. In her book Julia Kristeva: Psychoanalysis and Modernity, Sara Beardsworth asserts that "Because it (Christianity) identified abjection as a fantasy of devouring, Christianity effects its abreaction" $(2012,137)$. Therefore, shooting Bilal is a fantasy of devouring, as when the audience shoots Bilal with such vigor and robustness, he runs and tries to evade their shots, performing a ritual of purification by reenacting the murder of his brother Haji by the US drone. In so doing, Bilal's body has turned to be a sacrifice for all the bodies of the Iraqis killed by US drones. Further, these shooters experience a 'disavowal' of the abject's body, and some just log on the website without even shooting at him.

"Food loathing" is used as a technique in performance. It is achieved when Bilal does not hoard any food to eat later, as Becker writes, "For those guests who came to these events he probably appeared like the Hunger Artist in Kafka's parable" (2013, xix). Bilal relies entirely on the kindness of friends and strangers who bring food to him, as he says:

When I stepped into the paintball gallery for my month of captivity, I intentionally did not bring any food with me. I wanted to leave my fate, my well-being in the hands of the community, to take a leap of faith and hope they would care of (sic) me. (Shoot 2013, 62)

He sees that hoarding food will lessen his suffering and distract the audience from believing in his cause. Food is prohibited since Bilal is at war. Like soldiers at the line of fire, food is "an indulgence" (Bilal, Shoot 147) or a break from the shooting, as Bilal himself expresses:

\footnotetext{
I have always even as a child eating from the collective pot at the family meals, I would make my own plate with a controlled portion. But in the paintball project, food become (sic) one of the only sources of comfort and release, a kind of negotiating chip between my mind and body, an indulgence I granted myself to convince my body not to rebel against all the abuse. (Shoot 2013, 147)
}

Besides, Bilal does not want fixed times for his meals, nor does he want the online shooters to feel that he is at ease in his self-imposed incarceration. Kristeva holds that food becomes abject only "if it is a border between two distinct entities or territories. A boundary between nature and culture, between the human and the non-human" (Powers 1982, 75). The existence of daily meals is the boundary between war and peace. It is also the boundary between humans and nonhumans that is why food prohibitions and fasting are solemn and widespread traditions in all Abrahamic religions.

\section{CONCLUSION}

To conclude, previous scholarship has interpreted Wafaa Bilal's Domestic Tension within the framework of technology, audience participation, and geopolitics. However, this paper charts new grounds by looking at the performance from a psychological perspective, taking Julia Kristeva's theory of abjection as the methodology to analyse the performance. 
On camera, Bilal is exhausted, filthy, and stained with the yellow paint, which bears an uncanny resemblance to other bodily fluids such as blood and milk. This paper proves that Bilal's body becomes the 'maternal body' which makes the viewers abstain from 'shooting' it, thus suppressing their sexual desires. On the other hand, Bilal is also the homosexual whose body is penetrated rather than penetrating, insulted, and shot incessantly by the over-sexualised viewers who use a phallus-shaped robotic gun to shoot him. The paper finds out that the 'disavowal' of the 'maternal body' and the eroticising of the male body are two forces in collision inside the psyche of the viewers. Consequently, this provokes a strong reaction in the viewers who suddenly encounter a situation where they have to choose to watch or to shoot. If they choose to shoot, they abject Bilal, hence the disregard of his political anti-war message. It can be concluded that as an abject, Bilal stands on the borderline between life and death, between purity and defilement. Bilal, who represents the familiar foreigner, is suddenly recognized as a threat to national security by the American conservative ideology, so he must be shot and abjected. But if the viewers opt for just watching, they will end up thinking of the war on Iraq and what ensued in killing innocent people. In this way, abjection helps the viewers to choose their identity whether they are pro or anti-Iraq war.

Instead of pushing the abject to the margin to maintain a societal system and order, it is evident that Bilal succeeds in placing the abject in the center, before millions of viewers, leaving a gun in their hands to shoot or chat. The paper also highlights the use of the Brechtian technique, as in the use of the yellow-coloured pellets, where Bilal provides no comforting illusion to the viewers but rather awakens them to the killings of Iraqis by the US drones.

Bilal's choice to perform online breaks the limited space of the old traditional proscenium stage, opting for the liveliness of the theatre and freedom of performance, which lasted, as in the case of Domestic Tension, for thirty days. In so doing, Bilal asserts that theatre is a collaborative creation between performers and audience; a living experience being renewed every day with each new performance; and a ballot box where viewers cast their ballots by chatting or shooting the abject.

\section{REFERENCES}

Ali, H. M. (2013). The Abject Lover of the Courtly Love Era. 3L: Language, Linguistics, Literature ${ }^{\circledR}, 19(3)$.Beardsworth, S. (2012). Julia Kristeva: psychoanalysis and modernity. Suny Press.

Becker, C. (2013). Introduction: drawing the line. In Wafaa Bilal, Shoot an Iraqi: art, life, and resistance under the gun. New York: City Lights Books.

Beyst, S. (2002). Hermann Nitsch' Orgien Mysterien Theater. 1/9/2002. Online. Web. Retrieved Dec. 302017 from< $<$ http://d-sites.net/english/nitsch.html $>$.

Bilal, W. (2013). Shoot An Iraqi: art, life, and resistance under the gun. City Lights Books.

---. "A Virtual Jihadi." Online. Web. Retrieved April $1 \quad 2019 \quad$ from< http://www.wafaabilal.com/html/virtualJ.html $>$.

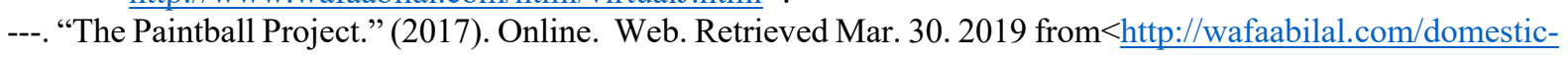
tension/>.

---. (2013). Shoot an Iraqi: art, life, and resistance under the gun. New York: City Lights Books.

Carroll, R., and Stephen Prickett, eds. (2008).The Bible: authorized king james version. OUP Oxford.

Covino, D. A. (1996). The Abject body: toward an aesthetic of the repulsive (Doctoral dissertation).

Felluga, D. (2019). Introduction to Julia Kristeva: modules on Kristeva. Online. Web. (2002). 12 Jan. https://www.cla.purdue.edu/english/theory/psychoanalysis/kristevadevelop.html.

Freud, S. (1955). Totem and taboo: Some points of agreement between the mental lives of savages and neurotics (1913 [1912-13]). In The Standard Edition of the Complete Psychological Works of Sigmund Freud, Volume XIII (1913-1914): Totem and Taboo and Other Works (pp. VII-162).

Gajanan, M. (2016). Feuds. TIME Magazine, 188(25-26), 34. http://search.ebscohost.com/login.aspx?direct=true\&db=a9h\&AN=120052871\&site=ehost-live.

Gilbertson, L. (2003). Andy Warhol's beauty\# 2: demystifying and reabstracting the feminine mystique, Obliquely. Art Journal, 62(1), 24-33. 
Gillespie, L. (2021). The Body as Real-Nostalgia Without Memory. In The Psychosocial Imaginaries of Defence Nationalism (pp. 143-173). Palgrave Macmillan, Cham.

Guler, S. D., Gannon, M., \& Sicchio, K. (2016). Superhumans and cyborgs. in crafting wearables (pp. 145-159). Apress, Berkeley, CA.

Hadley, B. (2017). Social Media as Theatre Stage: Aesthetics, Affordances, and Interactivities. In Theatre, Social Media, and Meaning Making (pp. 53-112). Palgrave Macmillan, Cham.

Joodaki, A. H., \& Elyasi, Z. (2015). Deconstructing Phallogocentrism in Shahrnush Parsipur's Touba and the Meaning of Night: A Psycho-Feminist Study. GEMA Online ${ }^{\circledR}$ Journal of Language Studies, 15(2).

Inbar, Y., Pizarro, D., Iyer, R., \& Haidt, J. (2012). Disgust sensitivity, political conservatism, and voting. Social Psychological and Personality Science, 3(5), 537-544.

Ingram, A. (2012). Experimental Geopolitics: Wafaa Bilal's domestic tension. The Geographical Journal, 178(2), 123-133.

Klein, N. (2007). The Shock Doctrine: The Rise of disaster capitalism. Macmillan. Education for Meaning and Social Justice 21.1, 53.

Kristeva, J. (1982). Approaching abjection. Oxford Literary Review, 5(1\2), 125-149.

---. (1982). Powers of horror: an essay on abjection. Trans. Leon S. Roudiez. New York: Colombia UP, 1982.

Kroker, A. \& Cook, D. (1987). The Postmodern scene: Excremental culture and hyper-aesthetics. New World Perspectives.

---. \& M. Kroker, eds. (1987). Body invaders: panic sex in america. New York: St. Martin's.

---. (1993). Spasm: virtual reality, android music, and electric flesh. New York: St. Martin's.

---. \& Kroker, M. (2016). Exits to the posthuman future: dreaming with drones. In Critical Posthumanism and Planetary Futures (pp. 75-90). Springer, New Delhi.

Kutzbach, K., \& Mueller, M. (2007). The Abject of desire: the aestheticization of the unaesthetic in contemporary literature and culture. BRILL.

Levin, L. (2014). Performing ground. in performing ground (pp. 67-95). Palgrave Macmillan, London.

Lewis, P. (2009). Machine rebellion begins: killer robots destroyed by the US jet. The Register. Co.UK. Sept. 15. online. $\quad$ web. 18 $<$ https://www.theregister.co.uk/2009/09/15/killer_robot_killed_by_fighter_jet/>

Lydersen, K. (2013). A Note on the writing of shoot an Iraqi. in Wafaa Bilal, shoot an Iraqi: art, life, and resistance under the gun. City Lights Books.

Haraway, D. \& Manifesto, A. C. (1991). Science, Technology, and Socialist-Feminism in The Late Twentieth Century. In Simians, Cyborgs and Women: The Reinvention of Nature (New York; Routledge, 1991), pp. 149-181.

Mi, L. S. (2019). Narrating the Diasporic Self as Shaman. Japanese Language and Literature, 53(2), 253-282.

Michaels, J. H. (2013). Shock and awe. in the discourse trap and the US military (pp. 81-106). Palgrave Macmillan, New York. (pp. 81-106).

Newell, J. (2013). Abject cyborgs: discursive boundaries and the remade in China miéville's iron council. Science Fiction Studies, 40(3), 496-509.

Oketch, F. O. (2013). Art and conversation: disturbation in public space (Doctoral dissertation, Oxford University, UK).

Oliver, K. (2014). Kristeva and food. in: thompson p.b., kaplan d.m. (eds) Encyclopedia of Food and Agricultural Ethics. Springer, Dordrecht.

---, K. (2009). Animal lessons: how they teach us to be human. Columbia University Press.

Parker-Starbuck, J. (2011). Shifting the balance: 'abject' bodies. In Cyborg Theatre (pp. 52-93). Palgrave Macmillan, London.

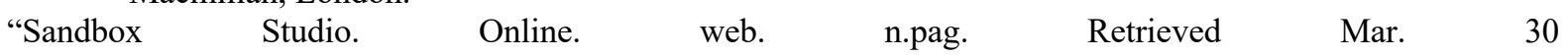
from $<$ (https://seechicagodance.com/organization/flatfile-gallery.>

Snæbjörnsdóttir, B., M. Wilson, and K. O’Reilly. (2017). Interview "Falling asleep with a pig."

Satkunananthan, A. H. (2015). The Baby's Not for Burning: The Abject in Sarah Kane's Blasted and Helen Oyeyemi's Juniper's Whitening. 3L: Language, Linguistics, Literature ${ }^{\circledR}, 21(2)$.

Stevens, L. (2014). Alienation in the information age: Wafaa Bilal's domestic tension. Australasian Drama Studies, (65), 77.

Wilke, S. \& Wilke-Gray, C. L. (2017). Performing hunger: fasting in franz kafka's hunger artist as poetic practice. In German Ecocriticism in the Anthropocene (pp. 147-164). Palgrave Macmillan, New York.

Wolfreys, J. (2003). Critical keywords in literary and cultural theory. Macmillan International Higher Education.

Zylka, R. R. (2010). Power performance: benevolence and violence in the work of chris burden, barbara t. smith, yoko ono, and wafaa bilal (Doctoral dissertation, University of Southern California). 